\title{
Differences in Inflammatory Cytokine Levels between Patients with Varying Severity of Chronic Venous Insufficiency
}

Lark G Guss ${ }^{1 *}$, Srimanasi Javvaji², Jamie Case ${ }^{3}$, Bethany Barrick BS ${ }^{3}$, Kathryn N Schaefer ${ }^{4}$, Ryan Gilbertson BS ${ }^{1}$, Jill Waalen ${ }^{5}$, Hugh T Greenway ${ }^{1}$ and Leland B Housman ${ }^{6}$

${ }^{1}$ Scripps Green Hospital, La Jolla, CA, USA

${ }^{2}$ Facial and Skin Surgery Center, EI Plano, TX, USA

${ }^{3}$ Scripps Bio-Repository and Scripps Center for Organ and Cell Transplantation, La Jolla, CA, USA

${ }^{4}$ Bio-Rad Laboratories, Hercules, CA, USA

${ }^{5}$ The Scripps Research Institute, La Jolla, CA, USA,

${ }^{6}$ Scripps Clinic Carmel Valley, Carmel Valley, CA, USA

\begin{abstract}
Objective: Several studies have found that protein concentrations of inflammatory cytokines are significantly increased in tissue and serum from patients with chronic venous insufficiency $(\mathrm{CVI})$ relative to that of healthy controls. We sought to determine whether inflammatory protein concentrations differ between patients with moderate clinical disease, classified as clinical, etiology, anatomy, pathophysiology (CEAP) Classes 2 and 3, and more severe clinical disease, classified as CEAP Class 4.
\end{abstract}

Methods: Twenty patients with abnormal venous function were included in the study. Blood from a competent leg vein and from an incompetent superficial vein was collected in addition to incompetent vein tissue extracted through a phlebectomy procedure. Cytokine levels of venous tissue lysate and serum samples were determined using a multiplex assay.

Results: Thirteen patients (65\%) were classified as clinical CEAP Class 2 or 3 , with seven patients (35\%) falling into the more severe Class 4 category. Twenty-seven cytokines were measured. Serum isolated from normal veins had significantly higher levels of IFN-gamma in patients with Classes 2 and 3 than Class 4 disease $(95.17 \mathrm{pg} / \mathrm{mL}$ vs. $71.97 \mathrm{pg} / \mathrm{mL} ; \mathrm{p}=0.036$ ). In serum from incompetent veins, IFN-gamma concentrations averaged $95.47 \mathrm{pg} / \mathrm{mL}$ in Class 2 and 3 patients and $76.97 \mathrm{pg} / \mathrm{mL}$ in Class 4 patients $(p=0.048)$. Eotaxin levels from diseased vein tissue averaged $3.37 \mathrm{pg} / \mathrm{mL}$ in Classes 2 and 3 patients, and $1.57 \mathrm{pg} / \mathrm{mL}$ in Class 4 patients $(p=0.037)$. IP-10 levels in diseased vein tissue was also significantly less in Class 4 patients at $74.20 \mathrm{pg} / \mathrm{mL}$ in Class 2 and 3 patients versus $31.06 \mathrm{pg} / \mathrm{mL}$ in Class 4 patients $(\mathrm{p}=0.004)$.

Conclusion: Despite several studies documenting increased inflammatory cytokines in patients with CVI, our study shows that those patients with more severe disease have significantly lower levels of several inflammatory cytokines. Thus, particular inflammatory cytokines may function in a reparative capacity following tissue injury or as a control mechanism to inhibit further tissue destruction.

Keywords: Chronic venous insufficiency; Inflammation; Cytokines; CEAP class; Venous reflux

\section{Introduction}

Chronic venous insufficiency (CVI) affects $10-20 \%$ of the population and is clinically characterized by persistent lower extremity edema due to underlying venous hypertension $[1,2]$. The spectrum of clinical sequelae ranges from persistent swelling and venous stasis changes to venous ulcers. Venous ulcers and non-healing wounds affect $0.2-1 \%$ of the population in developed countries and represent the most severe form of CVI $[3,4]$. Chronic lower extremity wounds, of which approximately $75 \%$ are due to CVI, are estimated to cause more than 2 million lost work days per year [5]. Though venous ulcers may be induced by trauma, the vast majority of them occur spontaneously [6].

Despite the high prevalence of CVI, it is curious that venous ulcers are relatively uncommon and the triggering factors remain unknown. Several studies have found that protein concentrations of inflammatory cytokines are significantly increased in tissue and serum from patients with CVI when compared to that of healthy controls $[7,8]$. Furthermore, many of these cytokines decrease following treatment $[7,8]$. However, it is unclear if the inflammatory milieu present in CVI contributes to disease pathogenesis, or if it is a repair response to tissue injury [9].

Though levels of inflammatory cytokines have been well documented to differ between CVI patients and healthy controls, the variability among patients and correlation with disease progression have not been well studied. We hypothesize that not only are cytokine levels different between healthy controls and diseased patients, inflammatory cytokine concentrations in serum and venous tissue are also different between patients with moderate clinical disease, classified as clinical, etiology, anatomy, pathophysiology (CEAP) Class 2 and 3, and more severe clinical disease, classified as CEAP Class 4.

\section{Materials and Methods}

\section{Clinical protocol}

Sample, data collection, and analysis for this study was approved

*Corresponding author: Lark Guss, Mohs Shiley Pavilion, 10820 N Torrey Pines Rd, La Jolla, CA 92037, USA, Tel: 760-831-9758; E-mail: Guss.lark@scrippshealth.org

Received March 07, 2018; Accepted March 30, 2018; Published April 06, 2018

Citation: Guss LG, Javvaji S, Case J, Barrick BSB, Schaefer KN, et al. (2018) Differences in Inflammatory Cytokine Levels between Patients with Varying Severity of Chronic Venous Insufficiency. J Vasc Med Surg 6: 363. doi: 10.4172/23296925.1000363

Copyright: @ 2018 Guss LG, et al. This is an open-access article distributed under the terms of the Creative Commons Attribution License, which permits unrestricted use, distribution, and reproduction in any medium, provided the original author and source are credited. 
Citation: Guss LG, Javvaji S, Case J, Barrick BSB, Schaefer KN, et al. (2018) Differences in Inflammatory Cytokine Levels between Patients with Varying Severity of Chronic Venous Insufficiency. J Vasc Med Surg 6: 363. doi: 10.4172/2329-6925.1000363

Page 2 of 6

by the Scripps Health Institutional Review Board. Informed consent following the principles outlined in the Declaration of Helsinki was obtained from each patient prior to enrollment. Inclusion criteria for this study included patients 18 years of age or older with abnormal venous function of the great saphenous vein or small saphenous vein. Additionally, patients were included only if they had a superficial segment of an incompetent vein requiring ambulatory phlebectomy for treatment as the vein was too superficial to safely treat with endovenous laser or chemical ablation. A Duplex ultrasonography scan (Philips Ultrasound, HD15 Diagnostic Ultrasound System, Bothel, WA, USA) to evaluate for vein size and reflux was performed with patients in a supine position, and CVI in the great or small saphenous veins was defined as the presence of reflux of $>0.5$ seconds.

Upon initial consultation for each patient, a baseline assessment for clinical, etiology, anatomy, and pathophysiology classification was recorded. Patients were ranked as CEAP Class 2, corresponding to large varicose veins; Class 3, corresponding to lower extremity edema; or Class 4, corresponding to venous stasis skin changes without evidence of ulceration.

\section{Tissue collection}

Incompetent superficial veins over the dorsal foot or ankle identified to have reflux were outlined with a tissue marker with the patient in the standing position. Local anesthesia was obtained through injection of $1 \%$ lidocaine and the vein was identified following subcutaneous incision. The vein was then ligated proximally and distally and the intervening vein was extracted and processed using the Bio-Plex cell lysis kit (Bio-PlexTM Cell Lysis Kit, Bio-Rad, Hercules, CA, USA).

\section{Serum collection}

Both control blood from a competent vein and blood from the incompetent vein were obtained from each patient at the time of their ambulatory phlebectomy procedure. Blood samples from the incompetent vein were acquired by puncturing the vein prior to ligation in the phlebectomy procedure described above. Control venous blood was taken from a competent vein in the lower leg, as demonstrated on Duplex ultrasonography as having no reflux.

\section{Analysis of cytokines in venous tissue and serum}

Cytokine levels of venous tissue lysate and serum samples were determined using the Bio-Plex Pro $^{\text {TM }}$ Human Cytokine 27-Plex Assay analyzed on a Bio-Plex 200 System (Bio-Rad, Hercules, CA, USA). Total protein concentration of venous tissue lysate was determined by the Lowry method and normalized to $210 \mu \mathrm{g} / \mathrm{ml}$ per reaction. Antibody-coupled capture beads were incubated with antigen standards or samples and run in duplicate, as per assay protocol. This was followed with incubation of biotinylated detection antibodies and reporter streptavidin-phycoerythrin ( $\mathrm{S}-\mathrm{P}$ ) conjugate. Beads were then passed through the Bio-Plex 200 suspension array reader according to the manufacturer's instructions. A $532 \mathrm{~nm}$ and $635 \mathrm{~nm}$ laser was used to excite the beads to determine the fluorescence intensity of bound $\mathrm{S}-\mathrm{P}$ and the bead identity, respectively. The Bio-Plex Manager ${ }^{\mathrm{TM}} 6.0$ software reported the concentration results in $\mathrm{pg} / \mathrm{mL}$.

\section{Statistical analysis}

Concentrations of inflammatory cytokines were not assumed to be a normal distribution. Differences between patient populations were analyzed using the Mann-Whitney U test. Significance was achieved when $\mathrm{p}<0.05$.

\section{Results}

\section{Patient demographics}

Twenty patients were enrolled in the study. Fourteen (70\%) were women and six (30\%) were men. Ages ranged from 39 to 76 years of age, with an average of 60.2 years. The majority of the patients were Caucasian $(80 \%)$ and the remaining $20 \%$ were of Hispanic origin (Table 1).

Each patient was evaluated for the number of endovenous ablative procedures performed. All patients underwent at least one endovenous laser ablation on either the great saphenous vein or small saphenous vein, and half of the patients had an endovenous laser ablation of both the great and small saphenous vein. The number of endovenous chemical ablations performed on each patient was also recorded. Patients ranged

\begin{tabular}{|c|c|c|c|c|c|c|}
\hline Sex & Age & Race & $\begin{array}{c}\text { Endovenous Laser } \\
\text { Ablations }\end{array}$ & $\begin{array}{c}\text { Endovenous } \\
\text { Chemical Ablations }\end{array}$ & $\begin{array}{c}\text { Total Procedure } \\
\text { Number }\end{array}$ & CEAP Class \\
\hline $\mathrm{F}$ & 72 & White & 4 & 8 & 12 & 3 \\
\hline $\mathrm{F}$ & 76 & White & 1 & 7 & 8 & 3 \\
\hline $\mathrm{F}$ & 71 & White & 2 & 6 & 8 & 4 \\
\hline$M$ & 51 & White & 2 & 4 & 6 & 4 \\
\hline $\mathrm{F}$ & 55 & White & 2 & 3 & 5 & 2 \\
\hline M & 39 & White & 2 & 10 & 12 & 4 \\
\hline M & 60 & White & 4 & 11 & 15 & 3 \\
\hline $\mathrm{F}$ & 61 & White & 1 & 3 & 4 & 3 \\
\hline M & 59 & White & 2 & 6 & 8 & 4 \\
\hline $\mathrm{F}$ & 70 & White & 1 & 8 & 9 & 2 \\
\hline $\mathrm{M}$ & 51 & Hispanic & 3 & 5 & 8 & 3 \\
\hline $\mathrm{F}$ & 73 & White & 4 & 8 & 12 & 4 \\
\hline $\mathrm{F}$ & 46 & White & 3 & 5 & 8 & 2 \\
\hline $\mathrm{F}$ & 69 & White & 2 & 3 & 5 & 3 \\
\hline $\mathrm{F}$ & 51 & White & 4 & 7 & 11 & 4 \\
\hline $\mathrm{F}$ & 68 & Hispanic & 2 & 2 & 4 & 3 \\
\hline $\mathrm{F}$ & 72 & Hispanic & 2 & 6 & 8 & 3 \\
\hline$M$ & 71 & White & 3 & 7 & 10 & 3 \\
\hline $\mathrm{F}$ & 42 & Hispanic & 2 & 9 & 11 & 3 \\
\hline $\mathrm{F}$ & 47 & White & 3 & 8 & 11 & 4 \\
\hline
\end{tabular}

Table 1: Demographics. 
Citation: Guss LG, Javvaji S, Case J, Barrick BSB, Schaefer KN, et al. (2018) Differences in Inflammatory Cytokine Levels between Patients with Varying Severity of Chronic Venous Insufficiency. J Vasc Med Surg 6: 363. doi: 10.4172/2329-6925.1000363

Page 3 of 6

from having a combined 4 endovenous laser and chemical ablations to 15 procedures, with an average of 8.75 procedures. Each patient also underwent at least one ambulatory phlebectomy procedure for a vein deemed too superficial to safely employ endovenous laser or chemical ablation.

Thirteen patients $(65 \%)$ were classified as Class 2 or 3, with seven patients (35\%) falling into the more severe Class 4 category. No patient fell into Class 5 or 6 , corresponding to a healed or present venous ulcer, respectively. The average age of Class 2 and 3 patients was not significantly different that the average age of Class 4 patients, 62.5 years vs. 55.9 years, respectively $(\mathrm{p}=0.23$ ). Additionally, the percentage of female patients in each group was not significantly different, $0.77 \%$ vs. $0.57 \%(\mathrm{p}=0.96)$

\section{Cytokine concentrations}

Twenty-seven cytokines were measured via a multiplex assay. In serum, nine cytokines (IL-2, IL-5, IL-6, IL-7, IL-10, IL-13, IL-15, MCP1 , and RANTES) were too low to be quantified accurately on a standard curve. In the vein tissue samples, ten cytokines' concentrations (IL1Ra, IL-4, IL-5, IL-8, IL-13, IL-15, G-CSF, PDGF, TNF-a, and VEGF) were too low to be measured. The data was queried for differences in protein concentrations found in serum obtained from normal veins and serum from diseased veins. Protein levels of eotaxin were found to be higher in serum taken from varicose veins, when compared to serum taken from a normal vein $(88.7 \mathrm{pg} / \mathrm{mL}$ vs. $78.7 \mathrm{pg} / \mathrm{mL}$; $=0.001)$. MIP$1 \mathrm{~B}$ levels were also higher in serum from varicose veins, $133 \mathrm{pg} / \mathrm{mL}$ vs. $128 \mathrm{pg} / \mathrm{mL}(\mathrm{p}=0.02)$, and RANTES was found in higher concentration in serum from varicose veins, $12650 \mathrm{pg} / \mathrm{mL}$ vs. $12301 \mathrm{pg} / \mathrm{mL}(\mathrm{p}=0.02)$.
No statistically significant difference was found in any of the other cytokines measured (Table 2).

Patients were then divided into groups with more moderate disease, CEAP Class 2 and 3, versus those patients with more severe disease, CEAP Class 4. Cytokine levels measured from serum obtained via healthy and diseased veins in each group are summarized in Tables 3 and 4 , respectively. Serum taken from normal veins had significantly higher protein levels of IFN-gamma in patients with Class 2 and 3 disease than Class 4 disease $(95.17 \mathrm{pg} / \mathrm{mL}$ vs. $71.97 \mathrm{pg} / \mathrm{mL}$; $\mathrm{p}=0.036$ ) (Figure 1). This finding was replicated in serum taken from a diseased varicose vein. IFN-gamma concentrations averaged $95.47 \mathrm{pg} / \mathrm{mL}$ in Class 2 and 3 patients and $76.97 \mathrm{pg} / \mathrm{mL}$ in Class 4 patients $(\mathrm{p}=0.048)$ (Figure 2).

Cytokine concentrations in diseased vein tissue lysates divided into CEAP classes are summarized in Table 5. Eotaxin protein levels averaged $3.37 \mathrm{pg} / \mathrm{mL}$ in Class 2 and 3 patients, and $1.57 \mathrm{pg} / \mathrm{mL}$ in Class 4 patients $(\mathrm{p}=0.037)$ (Figure 3$)$. The difference in protein concentration of IP-10 was also significantly less in Class 4 patients, measuring 74.20 $\mathrm{pg} / \mathrm{mL}$ in Class 2 and 3 patients, but only $31.06 \mathrm{pg} / \mathrm{mL}$ in Class 4 patients $(\mathrm{p}=0.004)$ (Figure 4).

\section{Discussion}

Tissue injury in CVI has been attributed to inflammatory processes responding to chronically elevated venous pressure. However, despite several studies documenting the presence of elevated inflammatory cytokines, the mechanism by which inflammation mediates tissue destruction has not been elucidated [6-10].

\begin{tabular}{|c|c|c|c|c|c|c|}
\hline \multicolumn{3}{|c|}{ Mean (SD) $(n=20)$} & \multirow[b]{2}{*}{ Normal Serum } & & \multicolumn{2}{|c|}{ Mean Paired Differences } \\
\hline Cytokine & Varicose Serum & & & & $\begin{array}{l}\text { Varicose Serum - } \\
\text { Normal Serum }\end{array}$ & $\begin{array}{l}\text { Protein } \\
\text { Concentration }\left(p^{*}\right)\end{array}$ \\
\hline IL-1b & 3.3 & 0.9 & 3.5 & 1 & -0.1 & 0.46 \\
\hline IL-1ra & 115 & 114 & 115 & 105 & 0.9 & 0.26 \\
\hline IL-2 & 0.1 & 0.6 & 0.005 & 0 & 0.1 & 0.99 \\
\hline IL-4 & 7.9 & 1 & 8.2 & 1.4 & -0.3 & 0.25 \\
\hline IL-5 & 0.6 & 2.6 & 0.9 & 2.4 & -0.3 & 0.75 \\
\hline IL-6 & 2.5 & 3.1 & 2.1 & 2.2 & 0.4 & 0.71 \\
\hline IL-7 & 0.7 & 2.1 & 0.9 & 2 & -0.2 & 0.2 \\
\hline IL-8 & 41 & 32.4 & 50.2 & 67.3 & -9.2 & 0.62 \\
\hline IL-9 & 138 & 38 & 132 & 36 & 6.5 & 0.28 \\
\hline IL-10 & 0.8 & 1.8 & 0.6 & 1.6 & 0.2 & 0.81 \\
\hline IL-12 & 44.5 & 59.3 & 43 & 46.1 & 1.5 & 0.99 \\
\hline IL-13 & 1.9 & 2.7 & 1.9 & 1.5 & -0.01 & 0.74 \\
\hline IL-15 & 0.005 & 0 & 0.005 & 0 & 0 & --- \\
\hline IL-17 & 90 & 87.9 & 86 & 82.7 & 4 & 0.33 \\
\hline Eotaxin & 88.7 & 37.9 & 78.7 & 33.6 & 10 & 0.001 \\
\hline Basic FGF & 102 & 65 & 96.5 & 54.4 & 5.5 & 0.89 \\
\hline G-CSF & 75.8 & 51.4 & 69.8 & 41.9 & 6.1 & 0.31 \\
\hline GMCSF & 70.5 & 104.4 & 55.6 & 79.5 & 14.8 & 0.53 \\
\hline IFN-g & 89 & 19.8 & 87.1 & 25.1 & 1.9 & 0.62 \\
\hline IP-10 & 592 & 242 & 580 & 272 & 11.3 & 0.22 \\
\hline MCP-1 & 1.6 & 6.9 & 4.1 & 12.7 & -2.6 & 0.75 \\
\hline MIP-1a & 7.5 & 6 & 7.7 & 5.4 & -0.2 & 0.73 \\
\hline MIP-1b & 133 & 64 & 128 & 60 & 5.8 & 0.02 \\
\hline PDGF-BB & 2707 & 648 & 2693 & 1059 & 13.4 & 0.7 \\
\hline RANTES & 12650 & 648 & 12301 & 841 & 349 & 0.02 \\
\hline TNF-a & 44.5 & 23.2 & 48.9 & 22.8 & -4.4 & 0.13 \\
\hline VEGF & 144 & 84 & 142 & 82 & 2.4 & 0.9 \\
\hline
\end{tabular}

Table 2: Mean paired differences in serum cytokines in healthy vs. diseased veins. 
Citation: Guss LG, Javvaji S, Case J, Barrick BSB, Schaefer KN, et al. (2018) Differences in Inflammatory Cytokine Levels between Patients with Varying Severity of Chronic Venous Insufficiency. J Vasc Med Surg 6: 363. doi: 10.4172/2329-6925.1000363

Page 4 of 6

\begin{tabular}{|c|c|c|c|c|c|c|}
\hline & \multicolumn{3}{|c|}{ Mean $(S D)(n=20)$} & & \multicolumn{2}{|c|}{ Mean Difference } \\
\hline & CEAP C & ass 2,3 & $\begin{array}{l}\text { CEAP } \\
\text { Class } 4\end{array}$ & & $\begin{array}{l}\text { CEAP 2,3- } \\
\text { CEAP 4 }\end{array}$ & $\begin{array}{c}\text { Protein } \\
\text { Concentration }\left(\mathrm{p}^{*}\right)\end{array}$ \\
\hline IL-1b & 3.4 & 0.9 & 3.7 & 1.2 & -0.3 & 0.522 \\
\hline IL-1a & 129.6 & 92.3 & 196.5 & 143.3 & -66.9 & 0.417 \\
\hline IL-4 & 8.2 & 1.6 & 8.3 & 1.1 & -0.1 & 0.918 \\
\hline IL-8 & 41.5 & 40.3 & 66.2 & 103.2 & -24.6 & 0.563 \\
\hline IL-9 & 130.4 & 43.6 & 133.6 & 19.0 & -3.2 & 0.822 \\
\hline IL-12 & 55.2 & 47.6 & 61.7 & 47.2 & -6.5 & 0.799 \\
\hline IL-17 & 103.6 & 95.3 & 92.3 & 64.7 & 11.3 & 0.769 \\
\hline Eotaxin & 84.0 & 40.1 & 68.8 & 13.3 & 15.2 & 0.230 \\
\hline $\begin{array}{l}\text { Basic } \\
\text { FGF }\end{array}$ & 109.8 & 65.8 & 99.5 & 37.0 & 10.2 & 0.648 \\
\hline G-CSF & 77.0 & 49.1 & 56.3 & 20.3 & 20.8 & 0.201 \\
\hline GM-CSF & 77.7 & 52.5 & 103.2 & 120.3 & -25.4 & 0.762 \\
\hline IFN-g & 95.2 & 24.5 & 72.0 & 19.6 & 23.2 & 0.036 \\
\hline IP-10 & 561.2 & 259.8 & 615.8 & 311.7 & -54.6 & 0.700 \\
\hline MIP-1a & 7.1 & 5.0 & 8.7 & 6.3 & -1.6 & 0.576 \\
\hline MIP-1b & 118.6 & 45.8 & 144.0 & 82.0 & -25.4 & 0.469 \\
\hline PDGF-BB & 2692.7 & 910.2 & 2693.9 & 1376.8 & -1.2 & 0.998 \\
\hline TNF-a & 48.6 & 26.4 & 49.6 & 15.7 & -1.0 & 0.917 \\
\hline VEGF & 141.2 & 78.9 & 163.0 & 91.7 & -21.8 & 0.600 \\
\hline
\end{tabular}

Table 3: Mean differences in serum cytokines from a healthy vein between CEAP classes.

\begin{tabular}{|c|c|c|c|c|c|c|}
\hline & \multicolumn{3}{|c|}{ Mean (SD) $(n=20)$} & & \multicolumn{2}{|c|}{ Mean Difference } \\
\hline & \multicolumn{2}{|c|}{ CEAP Class 2, 3} & \multirow{2}{*}{\begin{tabular}{|c|} 
CEAP \\
Class 4 \\
3.4
\end{tabular}} & \multirow[b]{2}{*}{1.1} & \multirow{2}{*}{\begin{tabular}{|c|}
$\begin{array}{c}\text { CEAP 2,3- } \\
\text { CEAP 4 }\end{array}$ \\
-0.2 \\
\end{tabular}} & \multirow{2}{*}{ 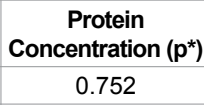 } \\
\hline IL-1b & 3.3 & 0.7 & & & & \\
\hline IL-1a & 148.3 & 118.2 & 149.8 & 125.5 & -1.5 & 0.983 \\
\hline IL-4 & 8.0 & 1.4 & 7.7 & 2.3 & 0.3 & 0.775 \\
\hline IL-8 & 38.9 & 21.1 & 45.0 & 49.1 & -6.1 & 0.764 \\
\hline IL-9 & 142.9 & 41.3 & 128.8 & 30.9 & 14.1 & 0.401 \\
\hline IL-12 & 75.9 & 62.3 & 71.8 & 57.3 & 4.1 & 0.911 \\
\hline IL-17 & 97.3 & 96.8 & 105.4 & 75.7 & -8.1 & 0.844 \\
\hline Eotaxin & 97.8 & 42.3 & 71.7 & 21.4 & 26.1 & 0.083 \\
\hline $\begin{array}{l}\text { Basic } \\
\text { FGF }\end{array}$ & 113.4 & 70.6 & 125.7 & 65.1 & -12.3 & 0.658 \\
\hline G-CSF & 82.9 & 59.6 & 62.7 & 30.5 & 20.2 & 0.331 \\
\hline GM-CSF & 94.6 & 62.6 & 182.2 & 157.8 & -87.6 & 0.397 \\
\hline IFN-g & 95.5 & 18.2 & 77.0 & 17.9 & 18.5 & 0.048 \\
\hline IP-10 & 618.3 & 236.2 & 542.2 & 264.0 & 76.1 & 0.536 \\
\hline MIP-1a & 7.1 & 6.2 & 8.2 & 6.0 & -1.1 & 0.717 \\
\hline MIP-1b & 124.9 & 50.1 & 149.0 & 87.1 & -24.1 & 0.518 \\
\hline PDGF-BB & 2750.4 & 946.6 & 2625.1 & 1823.1 & 125.4 & 0.869 \\
\hline TNF-a & 45.3 & 26.4 & 48.6 & 18.6 & -3.3 & 0.744 \\
\hline VEGF & 142.7 & 79.6 & 167.3 & 94.2 & -24.6 & 0.563 \\
\hline
\end{tabular}

Table 4: Mean differences in serum cytokines from a diseased vein between CEAP classes.

To explore the differences in cytokine levels between normal and elevated venous pressure environments, Lattimer et al. compared blood taken from the arm and the ankle in patients with CVI, as well as blood taken from both sites in healthy controls [10]. In their study, IL-6, IL-8, and MCP-1 all increased in concentration in the patients' legs when compared to the arms. However, the study found that IL-6 was also increased in legs of healthy controls when compared to arm blood. Thus, the authors hypothesized that IL-6 may reflect a normal physiologic response to high venous pressures rather than represent a biomarker of CVI or act as a mediator of disease. To better control for normal physiologic differences between upper and lower extremity cytokines, serum obtained from a non-diseased vein in our study was

\begin{tabular}{|c|c|c|c|c|c|c|}
\hline & \multicolumn{3}{|c|}{ Mean (SD) (n=20) } & & \multicolumn{2}{c|}{ Mean Difference } \\
\hline & \multicolumn{2}{|c|}{$\begin{array}{c}\text { CEAP Class } \\
\mathbf{2 , 3}\end{array}$} & $\begin{array}{c}\text { CEAP } \\
\text { Class 4 }\end{array}$ & & $\begin{array}{c}\text { CEAP 2,3- } \\
\text { CEAP 4 }\end{array}$ & $\begin{array}{c}\text { Protein } \\
\text { Concentration (p*) }\end{array}$ \\
\hline IL-1b & 0.1 & 0.1 & 0.1 & 0 & 0 & 0.332 \\
\hline IL-6 & 0.1 & 0.1 & 0.2 & 0.1 & 0 & 0.504 \\
\hline IL-7 & 2.2 & 1.1 & 2.7 & 2.1 & -0.6 & 0.527 \\
\hline IL-9 & 11.7 & 8.6 & 9 & 5.7 & 2.7 & 0.41 \\
\hline IL-10 & 3.1 & 1.7 & 4.1 & 2.6 & -1 & 0.359 \\
\hline IL-12 & 0.1 & 0.1 & 0.1 & 0.1 & 0 & 0.617 \\
\hline IL-17 & 4.7 & 5.1 & 6.2 & 4.1 & -1.5 & 0.492 \\
\hline Eotaxin & 3.4 & 2.6 & 1.6 & 0.8 & 1.8 & 0.037 \\
\hline Basic & 2.1 & 1.1 & 3.1 & 2.2 & -1 & 0.303 \\
\hline FGF & & & & & & \\
\hline GM-CSF & 0.9 & 0.6 & 1.5 & 1 & -0.6 & 0.157 \\
\hline IFN-g & 2.6 & 2 & 2.4 & 1.5 & 0.1 & 0.889 \\
\hline IP-10 & 74.2 & 37.1 & 31.1 & 21.7 & 43.1 & 0.004 \\
\hline MCP-1 & 5.4 & 4.3 & 3.9 & 3.3 & 1.6 & 0.432 \\
\hline MIP-1a & 0.5 & 0.2 & 0.5 & 0.3 & 0 & 0.861 \\
\hline MIP-1b & 8.9 & 7 & 6.3 & 4.4 & 2.6 & 0.317 \\
\hline RANTES & 711.8 & 756 & 330.4 & 237.1 & 381.5 & 0.114 \\
\hline
\end{tabular}

Table 5: Mean differences in vein tissue cytokines from a diseased vein between CEAP classes.

taken from a vein in the lower extremity which had been shown on Duplex ultrasonography to be of normal size without reflux.

An additional study by Tisato et al. used multiplexed beads to measure differences in 31 cytokines between plasma taken from within a normal vein and a diseased varicose vein, as well as plasma from healthy controls. The vast majority of cytokines were no different in CVI patients' plasma regardless of its source; only EGF, PDGF, and RANTES were noted to be increased at the varicose vein site [8]. Similarly, our data show very little difference in protein concentrations found in serum from a healthy versus a diseased vein, with only eotaxin, MIP-1B, and RANTES showing minimally increased concentrations. Thus, though cytokines are likely changed by the inflammatory process occurring in diseased veins, the circulating flow distributes inflammatory cytokines systemically.

When comparing CVI patients to healthy controls in the same study, 14 cytokines in blood samples from CVI patients showed increased levels. However, 6 months following a minimally invasive surgery to restore physiologic venous drainage (ambulatory conservative hemodynamic correction of venous insufficiency (CHIVA) procedure), several of the cytokine levels decreased to amounts similar to those seen in healthy controls [8]. A return to normal levels of inflammatory cytokines 6 months following a CHIVA procedure was also shown in an investigation by Zamboni et al. [11].

However, our study shows that among patients with CVI, those patients with more severe disease have significantly lower levels of several inflammatory cytokines, including IFN-gamma, eotaxin, and IP-10. Of note, no patients with venous ulceration were included in our study so the inflammatory changes involved in epidermal wound healing would not confound the results.

Thus, rather than a direct mediator of venous damage, particular inflammatory cytokines may function in a reparative capacity following tissue injury or as a control mechanism to inhibit further tissue destruction. Their decreased involvement may then allow for progression of CVI. Though numerous inflammatory mediators have been shown to be increased significantly in the peripheral blood of patients with CVI, levels do not necessarily correlate with clinical 
Citation: Guss LG, Javvaji S, Case J, Barrick BSB, Schaefer KN, et al. (2018) Differences in Inflammatory Cytokine Levels between Patients with Varying Severity of Chronic Venous Insufficiency. J Vasc Med Surg 6: 363. doi: 10.4172/2329-6925.1000363

Page 5 of 6

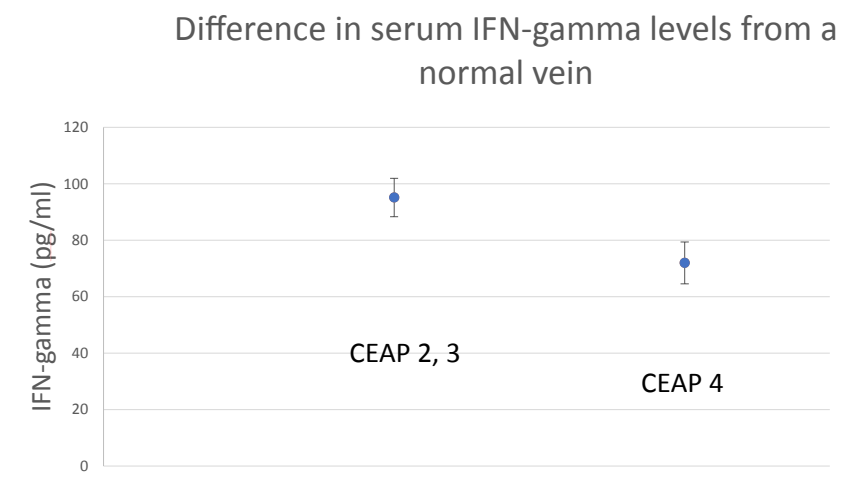

Figure 1: Difference in serum IFN-gamma levels from a healthy vein between CEAP classes.

Difference in serum IFN-gamma levels from a diseased vein

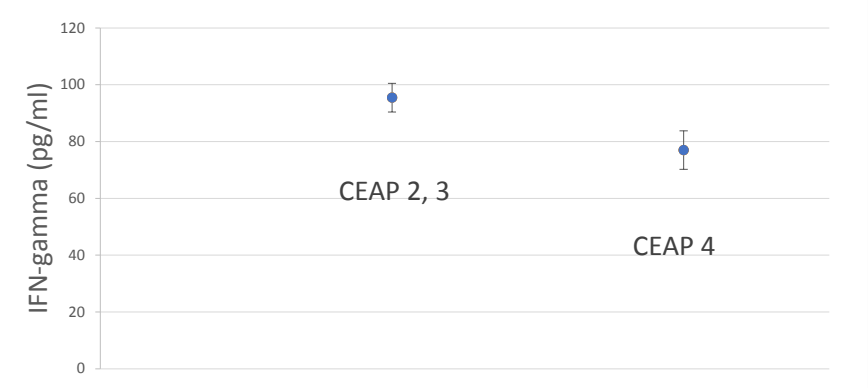

Figure 2: Difference in serum IFN-gamma levels from a diseased vein between CEAP classes.

\section{Difference in eotaxin levels from diseased vein tissue}

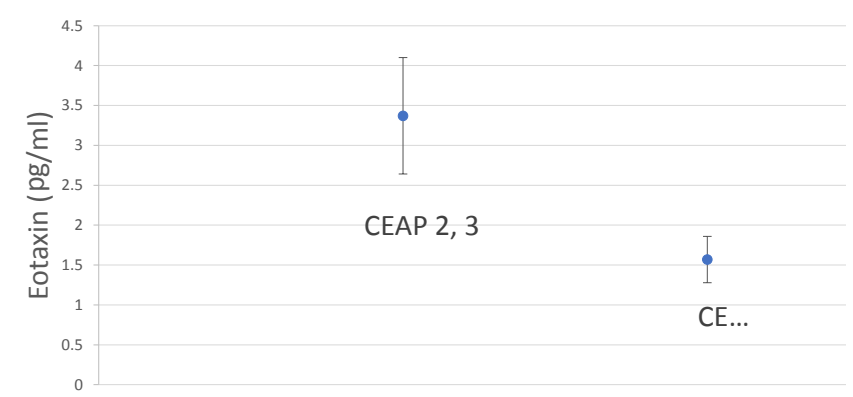

Figure 3: Difference in eotaxin levels from diseased vein tissue between CEAP classes.

symptoms. One study investigated cytokine levels in patients with CVI and found that though symptoms were worse in warmer weather, certain cytokines were much higher in autumn [12].

Limitations of our study include a small sample size of $\mathrm{C} 2$ patients as the difference in cytokine levels between $\mathrm{C} 2$ and $\mathrm{C} 3$ patients could not be evaluated in our study. Additionally, it would be interesting to investigate changes in cytokine levels 6 months following patients' treatment.

Rather than purely mediating destruction in venous disease, several previous studies have indicated that certain pro-inflammatory

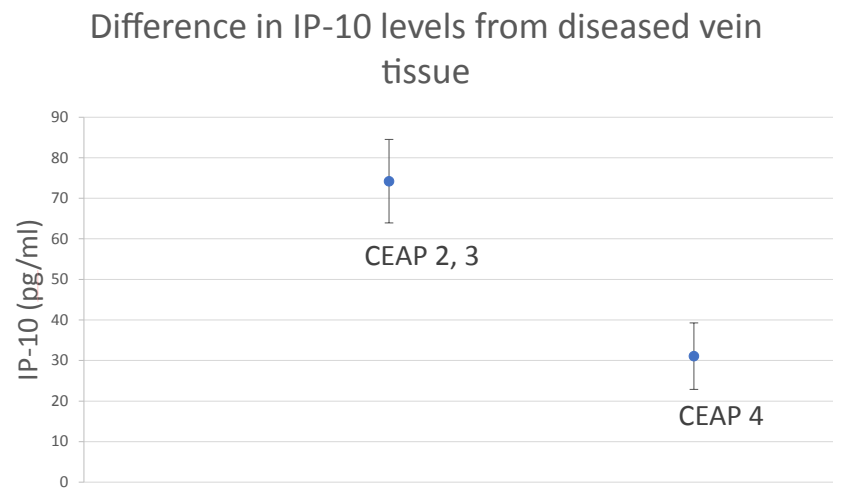

Figure 4: Difference in IP-10 levels from diseased vein tissue between CEAP classes.

cytokines may promote healing in the proper context. In patients with venous stasis ulcers, healing within 4 weeks of treatment with compression therapy was more likely in those patients with higher levels of IL-1a, IL-1b, IFN-gamma, IL-12p40, and GM-CSF [7]. In particular, total change in IFN-gamma levels was predictive of healing, further supporting IFN-gamma as a critical component of wound healing. In fact, several studies have found that lacking pro-inflammatory cells in acute wounds results in delayed healing $[13,14]$.

\section{Conclusion}

Despite the observation that inflammatory cytokines are increased in patients with CVI, the mechanism of tissue destruction has not been defined. Until now, it has been hypothesized that leukocytes are mediators of inflammatory tissue destruction. However, our study shows that several inflammatory markers, rather than continuing to increase with worsening clinical disease, actually decrease. Thus, it is possible that a component of the inflammatory milieu in CVI actually promotes healing and tissue repair.

\section{Acknowledgements}

We gratefully acknowledge the Scripps Clinic Bio-Repository for processing and providing the samples for this study. This research was funded by a Scripps Clinic Medical Group Research and Education grant.

\section{References}

1. Evans CJ, Allan PL, Lee AJ, Bradbury AW, Ruckley CV, et al. (1998) Prevalence of venous reflux in the general population on duplex scanning: the Edinburgh vein study. J Vasc Surg 28: 767-776.

2. Criqui MH, Jamosmos M, Fronek A, Denenberg JO, Langer RD, et al. (2003) Chronic venous disease in an ethnically diverse population: the San Diego Population Study. Am J Epidemiol 158: 448-456.

3. Simka M (2007) Calf muscle pump impairment and delayed healing of venous leg ulcers: air plethysmographic findings. J Dermatol 34: 537-544.

4. Simka M, Majewski E (2003) The social and economic burden of venous leg ulcers: focus on the role of micronized purified flavonoid fraction adjuvant therapy. Am J Clin Dermatol 4: 573-581.

5. McGuckin M, Waterman R, Brooks J, Cherry G, Porten L, et al. (2002) Validation of venous leg ulcer guidelines in the United States and United Kingdom. Am J Surg 183: 132-137.

6. Simka M (2006) A potential role of interferon-gamma in the pathogenesis of venous leg ulcers. Med Hypotheses 67: 639-644.

7. Beidler SK, Douillet CD, Berndt DF, Keagy BA, Rich PB, et al. (2009) Inflammatory cytokine levels in chronic venous insufficiency ulcer tissue before and after compression therapy. J Vasc Surg 49: 1013-1020.

8. Tisato V, Zauli G, Gianesini S, Menegatti E, Brunelli L, et al. (2014) Modulation of circulating cytokine-chemokine profile in patients affected by chronic venous 
Citation: Guss LG, Javvaji S, Case J, Barrick BSB, Schaefer KN, et al. (2018) Differences in Inflammatory Cytokine Levels between Patients with Varying Severity of Chronic Venous Insufficiency. J Vasc Med Surg 6: 363. doi: 10.4172/2329-6925.1000363

Page 6 of 6

insufficiency undergoing surgical hemodynamic correction. J Immunol Res 2014: 473765

9. Rosenkilde MM, Schwartz TW (2004) The chemokine system -- a major regulator of angiogenesis in health and disease. APMIS 112: 481-495.

10. Lattimer CR, Kalodiki E, Geroulakos G, Hoppensteadt D, Fareed J (2016) Are Inflammatory Biomarkers Increased in Varicose Vein Blood? Clin Appl Thromb Hemost 22: 656-664.

11. Zamboni P, Spath P, Tisato V, Tessari M, Dalla Caneva P, et al. (2016) Oscillatory flow suppression improves inflammation in chronic venous disease. J Surg Res 205: 238-245.
12. Spath P, Tisato V, Gianesini S, Tessari M, Menegatti E, et al. (2017) The calendar of cytokines: Seasonal variation of circulating cytokines in chronic venous insufficiency. JRSM Cardiovasc Dis 6: 2048004017729279.

13. Nagaoka T, Kaburagi $Y$, Hamaguchi $Y$, Hasegawa M, Takehara K, et al. (2000) Delayed wound healing in the absence of intercellular adhesion molecule-1 or L-selectin expression. Am J Pathol 157: 237-247.

14. Leibovich SJ, Ross R (1975) The role of the macrophage in wound repair. A study with hydrocortisone and antimacrophage serum. Am J Pathol 78: 71-100. 